AGRITECH, Vol. 37, No. 2, Mei 2017, Hal. 205-214

DOI: http://doi.org/10.22146/agritech.10497

ISSN 0216-0455 (Print), ISSN 2527-3825 (Online)

Tersedia online di https://jurnal.ugm.ac.id/agritech/

\title{
Optimasi Rendemen Fibroin Ulat Sutera Bombyx mori L. dan Attacus atlas L. dengan Response Surface Methodology
}

\author{
Optimization of Silkworm Fibroin Yield Bombyx mori L. and Attacus atlas L. Using Response Surface Methodology \\ Yuni Cahya Endrawati', Dedy Duryadi Solihin ${ }^{2}$, Ani Suryani $^{3}$, S. Subyakto ${ }^{4}$
}

\author{
${ }^{1}$ Departemen Ilmu Produksi dan Teknologi Peternakan, Fakultas Peternakan, Institut Pertanian Bogor, \\ Jl. Agatis Kampus IPB Dramaga, Bogor, Jawa Barat 16680, Indonesia \\ ${ }^{2}$ Departemen Biologi, Fakultas Matematika dan Ilmu Pengetahuan Alam, Institut Pertanian Bogor, \\ Jl. Agatis Kampus IPB Dramaga, Bogor, Jawa Barat 16680, Indonesia \\ ${ }^{3}$ Departemen Teknologi Industri Pertanian, Fakultas Teknologi Pertanian, Institut Pertanian Bogor, \\ Jl. Lingkar Akademik Kampus IPB Dramaga, Bogor, Jawa Barat 16680, Indonesia \\ ${ }^{4}$ Pusat Penelitian Biomaterial LIPI, Kawasan Cibinong Science Center, \\ Jl. Raya Bogor Km. 46, Cibinong, Bogor, Jawa Barat 16911, Indonesia \\ Email: y.cahya82@gmail.com
}

Submisi: 10 Februari 2016; Penerimaan: 2 Agustus 2016

\begin{abstract}
ABSTRAK
Ekstraksi fibroin dilakukan dengan perlakuan suhu dan waktu tanpa diketahui maksimal atau tidaknya capaian rendemen yang dihasilkan. Padahal data tersebut sangat penting untuk estimasi profitabilitas pada usaha hilir ulat sutera. Penelitian ini bertujuan untuk mendapatkan formulasi ekstraksi (degumming) yang menghasilkan rendemen fibroin optimum. Metode yang digunakan adalah optimasi ekstraksi fibroin menggunakan Response Surface Methodology (RSM) dengan tiga variabel bebas (konsentrasi $\mathrm{NaOH}$, suhu dan waktu). Variabel tersebut diformulasikan dalam rancangan percobaan Central Composite Design (CCD) menggunakan titik pusat $\mathrm{NaOH} 0,1 \mathrm{~N}$, suhu $105^{\circ} \mathrm{C}$ selama 30 menit. Pada rancangan percobaan tersebut, rendemen bobot fibroin (\%) digunakan sebagai respon (variabel terikat) untuk menghasilkan kondisi optimum. Kondisi tersebut berupa formulasi variabel bebas yang mengoptimumkan rendemen fibroin. Kondisi optimum Bombyx mori dicapai pada konsentrasi $\mathrm{NaOH} 0,018 \mathrm{~N}$, suhu $110,53^{\circ} \mathrm{C}$ dan waktu 55,51 menit pada satu kali degumming dengan perolehan rendemen fibroin sebesar 71,11 $\pm 0,98 \%$. Rendemen fibroin optimum sebesar 83,06 \pm $1,50 \%$ pada Attacus atlas dihasilkan dari kondisi optimum $\mathrm{NaOH} 0,12 \mathrm{~N}$, suhu $79{ }^{\circ} \mathrm{C}$ selama 42,65 menit pada dua kali degumming. Metode ekstraksi fibroin yang tepat akan menghasilkan rendemen fibroin yang optimum.
\end{abstract}

Kata kunci: Attacus atlas; Bombyx mori; fibroin; Response Surface Methodology (RSM); rendemen

\begin{abstract}
The fibroin extraction process was done based on temperature and time parameters without knowing exactly the rendement been maximum or not. Optimum rendement data are critical to the business feasibility for scaling up to the industrial level. The objective of this research was to obtain the optimum extraction process (degumming) to get the highest fibroin rendement. The method in this research was response surface method (RSM) where $\mathrm{NaOH}$ concentration, process temperature and time consumption were chosen to be independent variables. These variables were formulated in the central composite design (CCD) research method at RSM Program with the center point is $\mathrm{NaOH} 0.1 \mathrm{~N}, 105{ }^{\circ} \mathrm{C}$ for 30 minutes. The weight of fibroin yield (\%) being use as a response condition (dependent variable) to get the optimum result of fibroin rendement. The optimum degumming process condition of Bombyx mori
\end{abstract}


are achieved where the $\mathrm{NaOH} 0.018 \mathrm{~N}, 110,53{ }^{\circ} \mathrm{C}$ temperature degree for 55.51 minutes for a batch time process with the rendement recorded was $71.11 \pm 0.98 \%$. As for "Attacus atlas" the optimum rendement was $83.06 \pm 1.50 \%$ achieved at $0.12 \mathrm{~N} \mathrm{NaOH}$ concentration, process temperature was $79^{\circ} \mathrm{C}$ and 42.65 minutes for twice degumming. The best selected fribroin degumming method will lead to the optimum yield achievement.

Keywords: Attacus atlas; Bombyx mori; fibroin; Response Surface Methodology (RSM); yield

\section{PENDAHULUAN}

Serat sutera alami seperti yang dihasilkan Bombyx mori terdiri dari dua jenis protein yaitu fibroin dan serisin (Fabiani dkk., 1996). Protein fibroin merupakan protein serat sedangkan serisin merupakan perekatnya. Serisin membungkus filamen yang sangat kecil yaitu serat fibroin pada kokon, dengan persentase bobot fibroin sebesar $66,5-73,5 \%$ dan serisin sebesar 26,5-33,5\% dari total bobot kokon (Masahiro dkk., 2000; Sashina dkk., 2006). Attacus atlas merupakan salah satu spesies ulat sutera liar asli Indonesia yang mempunyai komposisi penyusun serat yang sama dengan $B$. mori, namun belum diketahui dengan pasti mengenai persentase dan karakteristik protein penyusunnya.

Fibroin B. mori mempunyai diameter $10-25 \mu \mathrm{m}$ yang terdiri dari tiga komponen yaitu high chain $350 \mathrm{kDa}$, low chain $26 \mathrm{kDa}$ dan glikoprotein $30 \mathrm{kDa}$ (Vepari dan Kaplan 2007; Mondal dkk., 2007). Fibroin termasuk dalam protein fibril atau serat yang tidak larut dalam air karena mempunyai ikatan hidrogen yang kuat dalam polimernya. Struktur molekulnya adalah makrofibril dengan lebar $6,5 \times 10^{5} \mathrm{~nm}$ yang terdiri dari kumpulan nanofibril berdiameter 90-170 $\mathrm{nm}$. Beberapa penelitian telah memanfaatkan fibroin $B$. mori sebagai biomaterial medis, diantaranya untuk tissue engineering, seperti penyembuhan luka, jaringan kardiak, jaringan keratomisit dan jaringan lain (Altman dkk., 2003; Byung dkk., 2004).

Pemanfaatan fibroin pada usaha hilir membutuhkan input fibroin yang maksimal dari proses ekstraksinya. Teknik ekstraksi fibroin yang tepat akan menghasilkan rendemen fibroin yang maksimal yang dibutuhkan untuk menganalisis profitabilitas usaha hilir ulat sutera. Ekstraksi fibroin berhubungan erat dengan pelarut dan suhu. Pemakaian jenis dan jumlah pelarut yang tidak tepat akan dapat merusak fibroin tetapi sebaliknya pemakaian yang tepat akan bermanfaat untuk mengekstraksi fibroin dengan baik. Fibroin toleran terhadap suhu hingga $140{ }^{\circ} \mathrm{C}$ (Moeliono dan Itung 2010), namun mulai mengalami perubahan struktur kimia pada suhu $180{ }^{\circ} \mathrm{C}$, dan mulai mengalami perubahan bentuk serta ukuran pada suhu $280{ }^{\circ} \mathrm{C}$ (Zhang dkk., 2002). Terkait dengan hal tersebut maka diperlukan suatu metode yang dapat menentukan variabel-variabel ekstraksi yang tepat serta pelarut dan suhu yang dapat mengoptimasi parameter, dalam hal ini adalah optimasi rendemen bobot fibroin. Hal ini penting dilakukan karena selama ini ekstraksi fibroin masih dilakukan secara konvensional pada satu perlakuan suhu dan waktu tanpa mengetahui rendemen optimal yang dapat dicapai sehingga seringkali terjadi penyusutan fibroin pada tahap pemanfaatan lanjut.

Metode yang banyak digunakan untuk tujuan optimasi adalah Response Surface Methodology (RSM) yang merupakan suatu fungsi pendekatan untuk meramalkan respon dan menentukan nilai-nilai dari variabel bebas yang dapat mengoptimumkan respon. Program tersebut banyak digunakan karena dapat meminimalkan jumlah pengamatan dengan menggunakan rancangan percobaan dan dapat menduga respon optimasi dengan fungsi persamaan respon yang dihasilkan. Program RSM juga mempunyai keunggulan lain yang tidak ada pada metode optimasi lainnya yaitu tahapan yang memberikan arah optimasi dengan mengakomodasi adanya steepest ascent/descent. Hasil analisis Program RSM ditampilkan dalam bentuk kontur yang menghasilkan titik optimum (kondisi optimum) berupa optimasi maksimum, minimum atau saddle point. Daerah optimum dapat diperoleh dari data percobaan sebelumnya tapi jika belum ada maka menggunakan steepest ascent method yang sering disebut dengan respon ordo pertama (Gasperz, 1992). Respon ordo pertama akan menghasilkan daerah optimum yang dipakai sebagai titik pusat dari respon ordo kedua. Desain respon ordo pertama dan kedua dapat dibantu dengan program software Program R versi 2.11.1 dengan packages 1.40 (Lenth 2010).

Tujuan dalam penelitian ini adalah menghasilkan formulasi ekstraksi fibroin (degumming) yang dapat menghasilkan rendemen fibroin optimum dari dua spesies kokon ulat sutera, B. mori dan A. atlas. Respon (variabel terikat) yang digunakan dalam penelitian ini adalah rendemen bobot fibroin (\%) yang merupakan hasil percobaan dari kombinasi variabel bebas (konsentrasi $\mathrm{NaOH}$, suhu dan waktu) ekstraksi menggunakan desain Central Composite Design (CCD) di Program RSM. Respon tersebut bermanfaat sebagai input pada Program RSM untuk menghasilkan kondisi optimum yang mengoptimumkan respon. Kondisi optimum tersebut kemudian diverifikasi di laboratorium dan dicek morfologi seratnya menggunakan Scanning Electron Microscopy (SEM). 


\section{METODE PENELITIAN}

\section{Material}

Material yang digunakan dalam penelitian adalah kulit kokon B. mori dari Pusat Litbang dan Peningkatan Produktivitas Hutan Ciomas Bogor, dan kulit kokon A. atlas dari Perkebunan Teh Walini Panglejar Purwakarta Jawa Barat dengan jumlah penggunaan sebesar $0,04 \mathrm{~g} / \mathrm{mL}$ untuk masingmasing jenis kulit kokon. Material lain yang digunakan adalah demineralited water dan $\mathrm{NaOH}$ Merck dengan perbandingan volume 2:1.

\section{Metode}

\section{Preparasi sampel}

Preparasi sampel untuk kokon A. atlas dan B. mori secara umum sama, meliputi pemisahan kulit kokon dari floss dan kotoran yang ada di dalam kokon (berupa sisa-sisa pupa mati). Preparasi sampel dimulai dengan membersihkan kokon utuh dari floss (serabut kokon) dan sisa pupa. Hasil dari pembersihan tersebut menghasilkan kulit kokon yang kemudian akan dibersihkan kembali dengan dicuci air bersih dan dikeringanginkan. Tahap selanjutnya adalah pemotongan kulit kokon hingga ukuran sekitar $1 \mathrm{~cm}^{2}$.

\section{Optimasi degumming}

Proses degumming merupakan tahap awal dalam ekstraksi fibroin sehingga membutuhkan metode yang tepat dalam menghasilkan fibroin yang bersih dari serisin namun mempunyai rendemen fibroin yang tinggi. Pada penelitian ini digunakan kombinasi degumming secara fisik dan kimia yang rancangannya dapat dilihat pada Tabel 1. Proses degumming dilakukan dua kali pengulangan dan jika hasil belum sesuai target (fibroin belum bersih dari serisin berdasarkan data SEM) maka degumming akan diulang kembali hingga kondisi optimum didapat. Hal ini untuk memastikan fibroin benar-benar bersih dari serisin. Alat yang digunakan untuk degumming adalah Tomy High Pressure Steam Sterilizer ES 315.

Tabel 1. Rancangan percobaan dengan central composite design (CCD)

\begin{tabular}{|c|c|c|c|c|c|c|}
\hline \multicolumn{3}{|c|}{ Kode variabel bebas } & \multicolumn{3}{|c|}{ Variabel bebas } & \multirow{3}{*}{$\begin{array}{c}\text { Respon atau variabel terikat } \\
\text { (rendemen bobot fibroin dalam \%) } \\
\mathrm{Y}\end{array}$} \\
\hline & & & Konsentrasi $\mathrm{NaOH}$ & Suhu & Waktu & \\
\hline$X_{1}$ & $X_{2}$ & $X_{3}$ & $\mathrm{~N}$ & ${ }^{\circ} \mathrm{C}$ & Menit & \\
\hline-1 & -1 & -1 & 0,05 & 95 & 20 & $\ldots$ \\
\hline-1 & -1 & 1 & 0,05 & 95 & 40 & $\ldots$ \\
\hline-1 & 1 & -1 & 0,05 & 115 & 20 & $\ldots$ \\
\hline-1 & 1 & 1 & 0,05 & 115 & 40 & $\ldots$ \\
\hline 1 & -1 & -1 & 0,15 & 95 & 20 & $\ldots$ \\
\hline 1 & -1 & 1 & 0,15 & 95 & 40 & $\ldots$ \\
\hline 1 & 1 & -1 & 0,15 & 115 & 20 & $\ldots$ \\
\hline 1 & 1 & 1 & 0,15 & 115 & 40 & $\ldots$ \\
\hline 0 & 0 & 0 & 0,1 & 105 & 30 & $\ldots$ \\
\hline 0 & 0 & 0 & 0,1 & 105 & 30 & $\ldots$ \\
\hline 0 & 0 & 0 & 0,1 & 105 & 30 & $\ldots$ \\
\hline 0 & 0 & 0 & 0,1 & 105 & 30 & $\ldots$ \\
\hline 0 & 0 & 0 & 0,1 & 105 & 30 & $\ldots$ \\
\hline 0 & 0 & 0 & 0,1 & 105 & 30 & $\ldots$ \\
\hline$-1,682$ & 0 & 0 & 0,0159 & 105 & 30 & $\ldots$ \\
\hline 1,682 & 0 & 0 & 0,1841 & 105 & 30 & $\ldots$ \\
\hline 0 & $-1,682$ & 0 & 0,1 & 88,18 & 30 & $\ldots$ \\
\hline 0 & 1,682 & 0 & 0,1 & 121,82 & 30 & $\ldots$ \\
\hline 0 & 0 & $-1,682$ & 0,1 & 105 & 13,18 & $\ldots$ \\
\hline 0 & 0 & 1,682 & 0,1 & 105 & 46,82 & $\ldots$ \\
\hline
\end{tabular}




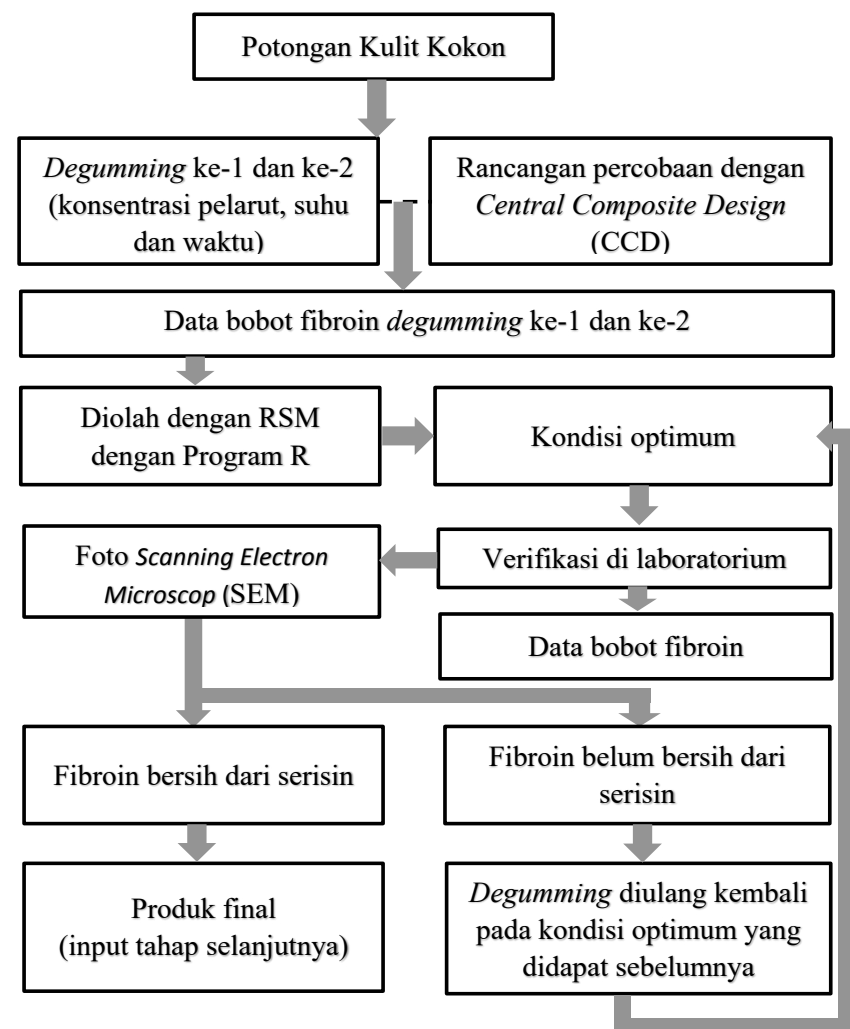

Gambar 1. Diagram alir optimasi degumming

Bobot kokon hasil percobaan berdasarkan CCD (variabel Y pada Tabel 1) diolah dengan Program RSM (Lenth, 2010) untuk menghasilkan persamaan sebagai standar penduga nilai respon (rendemen bobot fibroin) pada percobaan degumming kulit kokon ulat sutera selanjutnya. Pengolahan dengan Program ini, juga menghasilkan kondisi optimum yang akan mengoptimalkan respon (variabel Y yang optimum). Kondisi optimum kemudian diverifikasi di laboratorium untuk mengetahui respon (rendemen bobot fibroin) sesungguhnya. Skema optimasi degumming disajikan pada Gambar 1.

\section{Peubah}

\section{Rendemen bobot fibroin (\%)}

Rendemen bobot fibroin digunakan sebagai respon dalam RSM dan dihitung dengan Persamaan 1.

Rendemen bobot fibroin $(\%)=\frac{\text { Bobot fibroin }}{\text { bobot kulit kokon }} \times 100 \%$

\section{Scanning Electron Microscopy (SEM)}

Analisis SEM digunakan untuk melihat morfologi fibroin, sehingga fibroin akan terlihat dengan jelas apakah telah bersih dari serisin atau tidak. Alat SEM yang digunakan adalah Carl Zeiss Bruker EVO MA10 Germany. Pada proses awal analisis SEM, fibroin yang diletakkan pada template tembaga dilapisi emas tipis terlebih dahulu sebelum dimasukkan dalam alat SEM untuk melihat morfologi seratnya. Emas tipis tersebut berfungsi sebagai conductive coating untuk meningkatkan pencitraan gambar yang dihasilkan oleh SEM.

\section{Uji Kekuatan Tarik Serat Tunggal Fibroin}

Uji Kekuatan Tarik bermanfaat untuk mengetahui kekuatan tarik dari serat tunggal. Uji kekuatan tarik menggunakan alat Autograph Shimazu AG-IS 50kN Japan dengan kecepatan 0,1 mm/menit dan force 0,5 N. Preparasi sampel untuk uji Kekuatan Tarik dimulai dengan pembuatan papan penjepit fibroin tunggal yang terbuat dari karton. Dibutuhkan tiga buah karton penjepit yang terdiri dari dua karton ukuran 5 x $5 \mathrm{~cm}$ dan satu karton 5 x $15 \mathrm{~cm}$. Masingmasing fibroin tunggal berukuran panjang $15 \mathrm{~cm}$ dengan 5 $\mathrm{cm}$ diujung satu dijepitkan pada karton $(5 \times 5 \mathrm{~cm})$, dan $5 \mathrm{~cm}$ di ujung yang lain dijepitkan pada karton $(5$ x $5 \mathrm{~cm})$. Karton ukuran 5 x $15 \mathrm{~cm}$ akan ditutupkan dibagian belakang dan sampel kemudian akan diuji Kekuatan Tarik.

\section{Analisis}

Program Response Surface Methodology (RSM) merupakan analisis yang digunakan untuk mendapatkan rendemen fibroin optimum dari kedua spesies (A. atlas dan $B$. mori). Ada dua tahapan yang digunakan dalam RSM, yaitu penentuan ordo pertama (daerah optimum) dan ordo kedua (titik optimum atau kondisi optimum). Daerah optimum (ordo pertama) ditentukan dari percobaan sebelumnya sehingga analisis ordo pertama tidak dilakukan lagi. Analisis ordo kedua (kondisi optimum) menggunakan fungsi sebagai berikut:

$Y=\beta_{\mathrm{o}}+\beta_{1} \mathrm{X}_{1}+\beta_{2} \mathrm{X}_{2}+\beta_{3} \mathrm{X}_{3}+\beta_{11} \mathrm{X}_{1}^{2}+\beta_{22} \mathrm{X}_{2}^{2}+\beta_{33} \mathrm{X}_{3}^{2}+$
$\beta_{12} \mathrm{X}_{1} \mathrm{X}_{2}+\beta_{13} \mathrm{X}_{1} \mathrm{X}_{3}+\beta_{23} \mathrm{X}_{2} \mathrm{X}_{3}+\mathrm{C}$

Keterangan: $Y=$ Respon (rendemen bobot fibroin); $\beta_{\mathrm{o}}=$ konstanta; $\beta_{\mathrm{i} . . .} \beta_{\mathrm{ij}}$ $=$ koefesien dari variabel bebas $(i=1,2,3)$ pada ulangan ke-j $(1,2,3) ; \mathrm{X}_{1} \mathrm{X}_{2}$ dan $\mathrm{X}_{3}=$ variabel bebas yang digunakan; dan $\mathcal{\Theta}$ $=$ galat atau error .

Rancangan percobaan ordo kedua menggunakan Central Composite Design (CCD) dari Program RSM dengan tiga variabel bebas $\left(2^{3}\right)$ yaitu konsentrasi $\mathrm{NaOH}\left(\mathrm{X}_{1}\right)$, suhu $\left(\mathrm{X}_{2}\right)$, dan waktu $\left(\mathrm{X}_{3}\right)$ dengan $\alpha=1,682$ (Tabel 1). Rancangan percobaan $\mathrm{CCD}$ membutuhkan titik pusat (dinotasikan dengan angka nol pada Tabel 1) sebagai titik awal perlakuan yang merupakan daerah optimum pada hasil ordo pertama. Titik pusat yang digunakan adalah konsentrasi $\mathrm{NaOH} 0,1 \mathrm{~N}$, suhu $105^{\circ} \mathrm{C}$ dan waktu 30 menit (Endrawati, 2012). 


\section{HASIL DAN PEMBAHASAN}

\section{Kondisi Optimum Fibroin B. mori}

Kondisi optimum merupakan hasil dari proses optimasi suatu rendemen menggunakan Program RSM. Optimasi fibroin pada $B$. mori menggunakan dua data yaitu hasil satu kali degumming (DIb) dan dua kali degumming (DIIb). DIb menghasilkan kondisi optimum pada $0,018 \mathrm{~N} \mathrm{NaOH}$, suhu $110,53{ }^{\circ} \mathrm{C}$ dan waktu 55,51 menit, sedangkan DIlb menghasilkan kondisi optimum pada $0,12 \mathrm{~N} \mathrm{NaOH}$, suhu $83,18^{\circ} \mathrm{C}$ dan waktu 43,86 menit. Hasil pengolahan dengan Program RSM didapatkan eigenvalue masing-masing adalah $-0,188$ (NaOH), -0,704 (suhu) dan -3,863 (waktu) untuk DIb, serta 3,268 (NaOH), 0,907 (suhu) dan -2,250 (waktu) untuk DIIb. Hal ini berarti bahwa respon yang dihasilkan oleh DIb menghasilkan rendemen fibroin yang maksimal, sedangkan dari DIIb menghasilkan optimasi yang saddle point. Hal tersebut juga diperlihatkan dari gambar konturnya (Gambar 2 dan Gambar 3). Kriteria mengenai hasil optimasi didasarkan pada Myer (1971), jika semua eigenvalue bernilai positif maka optimasi menjadi minimum, jika semua nilai bernilai negatif maka optimasi menjadi maksimum dan jika didapat nilai positif dan negatif maka optimasi menjadi saddle point atau pelana kuda.

Pada kontur (Gambar 2) memperlihatkan bahwa kombinasi nilai variabel bebas pada satu kali degumming $B$. mori menghasilkan respon (bobot fibroin) yang maksimum, ditunjukkan dengan gambar kontur yang memusat dengan nilai yang semakin besar pada semua kombinasi variabel bebas. Berbeda halnya pada Gambar 3, kontur memperlihatkan optimasi saddle point yang ditunjukkan dengan kombinasi variabel bebas yang tidak semua memusat. Kombinasi konsentrasi $\mathrm{NaOH}$ dan suhu (Gambar 3a) serta kombinasi suhu dan waktu (Gambar 3c) belum menunjukkan respon yang optimum ditandai dengan tidak adanya kontur yang memusat. Hal ini kemungkinan karena perlakuan tidak bekerja pada kisaran nilai variabel bebas yang tepat dan ordo pertama (titik pusat) yang digunakan masih diluar kisaran optimumnya. Berbeda halnya dengan kombinasi konsentrasi $\mathrm{NaOH}$ dan waktu (Gambar 3c) memperlihatkan kontur yang memusat namun dengan nilai yang semakin mengecil, serta eigenvalue yang positif dikedua variabel $\left(\mathrm{X}_{2}=0,369 ; \mathrm{X}_{3}=\right.$ 1,386). Hal ini menunjukkan bahwa kombinasi variabel bebas tersebut menghasilkan optimasi yang minimum, yang berarti bahwa ekstraksi fibroin dengan dua kali degumming menghasilkan rendemen bobot fibroin yang semakin kecil.

Kondisi optimum di atas dapat dijadikan referensi untuk proses optimasi pada degumming fibroin ulat sutera B. mori. Oleh karena selama ini belum ada penggunaan metode optimasi dengan Program RSM untuk menentukan kondisi optimum degumming fibroin. Selama ini degumming hanya dilakukan dengan kombinasi fisik dan kimia tanpa mengetahui perolehan rendemen fibroin tersebut telah maksimal atau belum. Metode optimasi tersebut memang pernah digunakan untuk material fibroin namun pada kajian yang berbeda. Program RSM pernah digunakan untuk mengoptimasi pengaruh electrospinning terhadap diameter nanofibroin (Amiraliyan dkk., 2009).
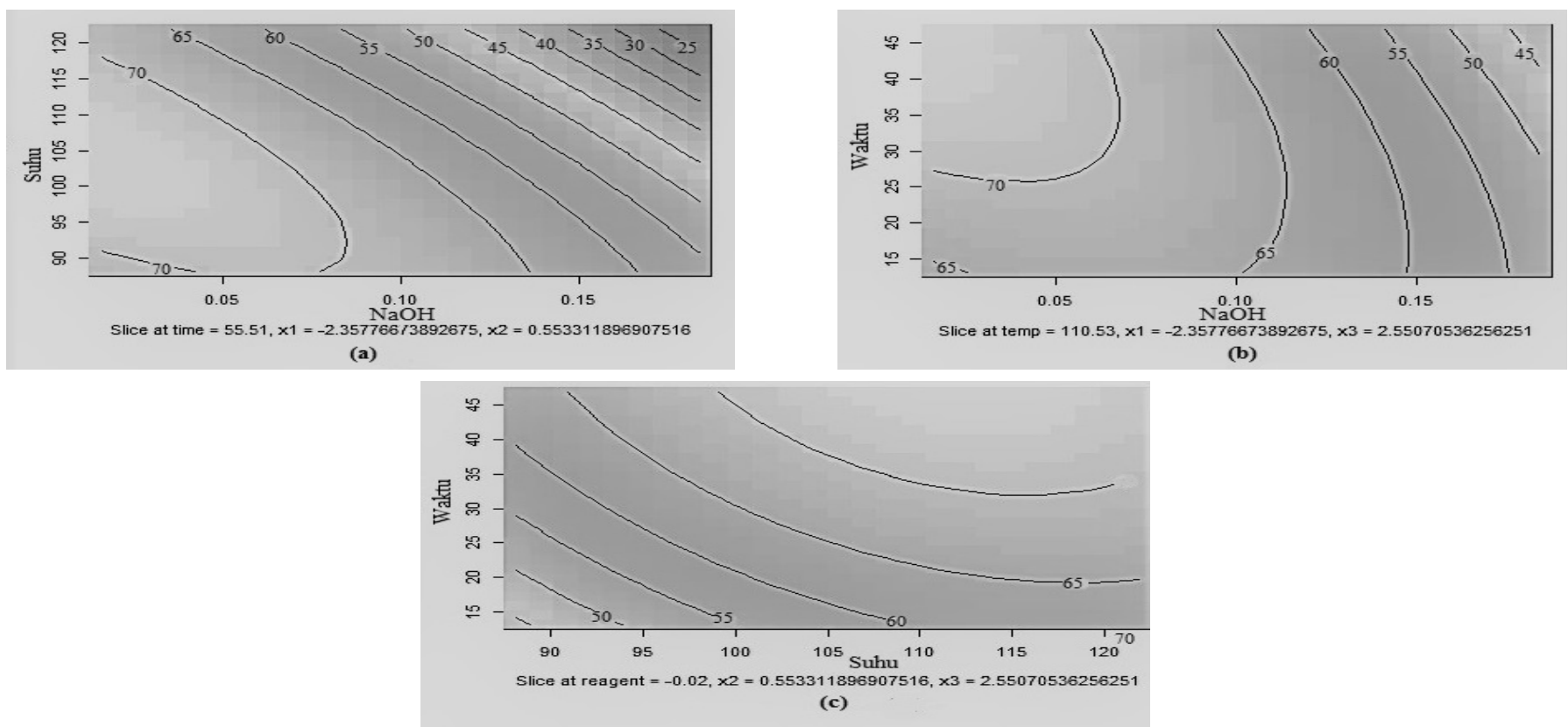

Gambar 2. Kontur rendemen bobot fibroin B. mori dengan satu kali degumming, a) kombinasi konsentrasi $\mathrm{NaOH}$ dan suhu, b) kombinasi konsentrasi $\mathrm{NaOH}$ dan waktu, dan c) kombinasi suhu dan waktu 


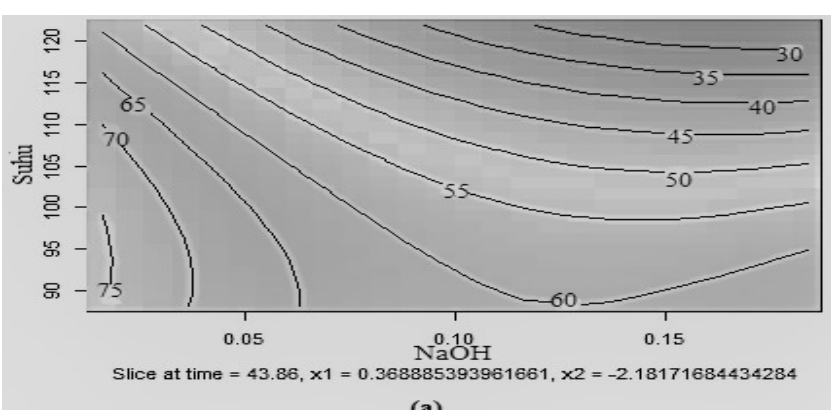

(a)

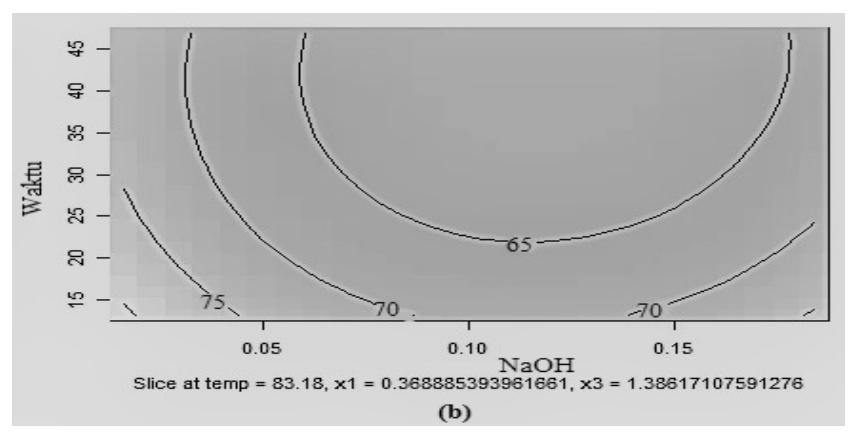

(b)

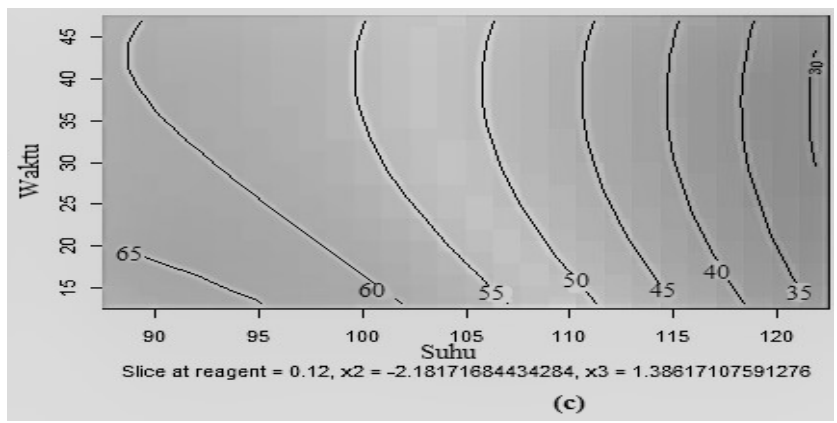

Gambar 3. Kontur rendemen bobot fibroin B. mori dengan dua kali degumming, a) kombinasi konsentrasi $\mathrm{NaOH}$ dan suhu, b) kombinasi konsentrasi $\mathrm{NaOH}$ dan waktu, dan c) kombinasi suhu dan waktu

Rendemen bobot fibroin dapat diduga juga dari fungsi persamaan yang dihasilkan oleh pengolahan Program RSM (Persamaan 3 untuk DIb dan Persamaan 4 untuk DIIb) tanpa melakukan percobaan di laboratorium. Fungsi persamaan yang dihasilkan sebagai berikut:

$$
\begin{aligned}
& Y=69,15-4,48 X_{1}-3,47 X_{2}+0,12 X_{3}-2,25 X_{1}^{2}-1,76 X_{2}^{2}- \\
& 0,74 X_{3}^{2}-3,14 X_{1} X_{2}-1,73 X_{1} X_{3}-0,78 X_{2} X_{3} \\
& Y=53,52-6,39 X_{1}-8,67 X_{2}-1,67 X_{3}+3,06 X_{1}^{2}-2,05 X_{2}^{2}+ \\
& 0,91 X_{3}^{2}-2,04 X_{1} X_{2}-0,23 X_{1} X_{3}+0,35 X_{2} X_{3}
\end{aligned}
$$

Keterangan: $\mathrm{Y}=$ respon (rendemen bobot fibroin), $\mathrm{X}_{1}=$ konsentrasi $\mathrm{NaOH}$, $\mathrm{X}_{2}=$ suhu dan $\mathrm{X}_{3}=$ waktu.

Program RSM menunjukkan nilai $\mathrm{R}^{2}$ sebesar 0,9645 untuk fungsi Persamaan 3 yang berarti bahwa variabel bebas yang digunakan dapat menjelaskan variabel terikat (respon rendemen bobot fibroin) sebesar 96,45\%. Nilai tersebut mengindikasikan bahwa fungsi persamaan yang dihasilkan memiliki goodness of fit yang baik karena nilainya mendekati satu. Persamaan 4 menunjukkan nilai $\mathrm{R}^{2}$ sebesar 0,8874 yang berarti bahwa variabel bebas hanya bisa menjelaskan respon sebesar $88,74 \%$ sedangkan $11,26 \%$ dipengaruhi faktor lain. Hal ini juga terlihat pada perhitungan respon rendemen bobot fibroin $B$. mori dengan subtitusi nilai stationary point pada masing-masing persamaannya. Nilai stationary point untuk Persamaan 3 adalah $X_{1}(-2,36), X_{2}(0,55)$ dan $X_{3}$ $(2,55)$, sedangkan untuk Persamaan 4 adalah $X_{1}(0,37), X_{2}$
$(-2,18)$ dan $X_{3}(1,39)$. Subtitusi tersebut menghasilkan respon rendemen bobot fibroin yang lebih tinggi pada Persamaan 3 yaitu sebesar 73,64\% dan 60,64\% untuk Persamaan 4 .

Verifikasi kondisi optimum juga dilakukan di laboratorium dengan hasil rendemen fibroin $B$. mori $\mathrm{DIb}$ sebesar 71,11 $\pm 0,98 \%$ dan DIIb sebesar 70,76 $\pm 0,90 \%$. Hasil tersebut tidak berbeda nyata $(p>0,05)$ sehingga DIb yang direkomendasikan sebagai standar formulasi degumming pada kulit kokon B. mori. Hal ini karena hanya dengan sekali degumming dapat menghasilkan bobot fibroin yang tidak berbeda nyata dengan dua kali degumming dan sesuai juga dengan gambar konturnya (Gambar 2 dan Gambar 3). Hasil rendemen tersebut juga masuk pada kisaran hasil penelitian Shasina dkk. (2006) sebesar 66,5-73,5\%, yang degumming nya menggunakan kombinasi fisik dan kimia namun tanpa uji optimasi rendemen. Hasil foto SEM fibroin juga memperlihatkan bahwa DIb lebih bersih fibroinnya dibandingkan DIIb (Gambar 4).

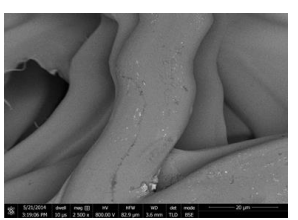

(a)

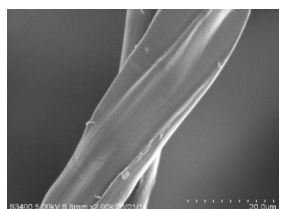

(b)

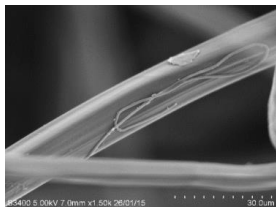

(c)
Gambar 4. Hasil foto SEM fibroin B. mori: a) fibroin sebelum degumming, b) satu kali degumming (DIb) pada 0,018 N NaOH, suhu 110,53 ${ }^{\circ} \mathrm{C}$ dan waktu 55,51 menit, serta c) dua kali degumming (DIIb) pada $0,12 \mathrm{~N} \mathrm{NaOH}$, suhu $83,18^{\circ} \mathrm{C}$ dan waktu 43,86 menit 


\section{Kondisi Optimum Fibroin A. atlas}

Optimasi degumming pada kokon A. atlas sangat diperlukan karena belum ada data terkait dengan hal tersebut. Padahal dalam upaya pemanfaatan lebih lanjut (usaha hilir ulat sutera), optimasi proses degumming sangat dibutuhkan untuk efisiensi produksi dan memastikan profitabilitas usaha. Pada penelitian ini optimasi fibroin $A$. atlas juga dilakukan seperti pada $B$. mori yaitu dengan dua kali degumming. Pada satu kali degumming (DIa) dihasilkan kondisi optimum 0,07 $\mathrm{N} \mathrm{NaOH}$, suhu $482,8^{\circ} \mathrm{C}$, dan waktu 202,8 menit, sedangkan dua kali degumming (DIIa) dihasilkan kondisi optimum pada $0,12 \mathrm{~N} \mathrm{NaOH}$, suhu $79,3{ }^{\circ} \mathrm{C}$, dan waktu 42,65 menit. Fungsi persamaan yang diperoleh adalah:

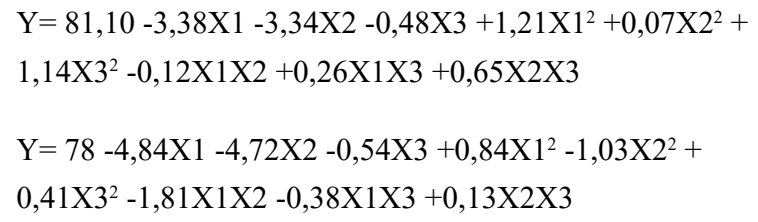

Keterangan: $Y=$ respon (rendemen bobot fibroin), $\mathrm{X}_{1}=$ konsentrasi $\mathrm{NaOH}$, $\mathrm{X}_{2}=$ suhu dan $\mathrm{X}_{3}=$ waktu.

Fungsi persamaan tersebut mempunyai $\mathrm{R}^{2}$ sebesar 0,956 untuk Persamaan 5 dan 0,9695 untuk Persamaan 6. Nilai $\mathrm{R}^{2}$ untuk kedua fungsi persamaan sudah baik karena mendekati nilai satu. Fungsi persamaan tersebut dapat digunakan untuk menduga kisaran bobot fibroin tanpa melakukan percobaan di laboratorium dengan cara subtitusi nilai stationary point ke dalam persamaan. Nilai stationary point untuk Persamaan 5 adalah $X_{1}(-3,39), X_{2}(-58,78)$ dan $X_{3}(17,28)$, sedangkan untuk Persamaan 6 adalah $X_{1}(0,40), X_{2}(-2,57)$ dan $X_{3}(1,26)$. Subtitusi tersebut menghasilkan perhitungan respon sebesar 159,42\% untuk Persamaan 5 dan 82,74\% untuk Persamaan 6.

Kondisi optimum yang diperoleh menghasilkan respon saddle point karena eigenvalue ada yang bernilai positif dan ada yang negatif, yaitu 1,334 $(\mathrm{NaOH}), 1,113$ (suhu) dan -0.027 (waktu) untuk DIa, serta 1,251 ( NaOH), 0,362 (suhu) dan -1.393 (waktu) untuk DIIa. Hal ini berarti bahwa kondisi optimum belum tercapai, diperlihatkan juga oleh gambar konturnya (Gambar 5 dan Gambar 6). Oleh karena itu dilakukan verifikasi percobaan di laboratorium dan cek foto SEM nya.

Gambar kontur pada satu kali degumming A. atlas memperlihatkan tidak tercapainya kondisi optimum yang ditunjukkan dengan tidak adanya garis-garis kontur hampir pada semua kombinasi variabel (Gambar 5). Hal ini terjadi karena kondisi optimum pada satu kali degumming berada jauh dari titik pusat yang digunakan dalam percobaan, sehingga garis tidak dapat terlihat. Gambar kontur pada dua kali degumming juga memperlihatkan optimasi yang saddle point (Gambar 6). Hanya ada satu kombinasi variabel yang memusat yaitu pada kombinasi konsentrasi $\mathrm{NaOH}$ dan waktu (Gambar 6b).

Verifikasi perlu dilakukan untuk mengetahui perolehan
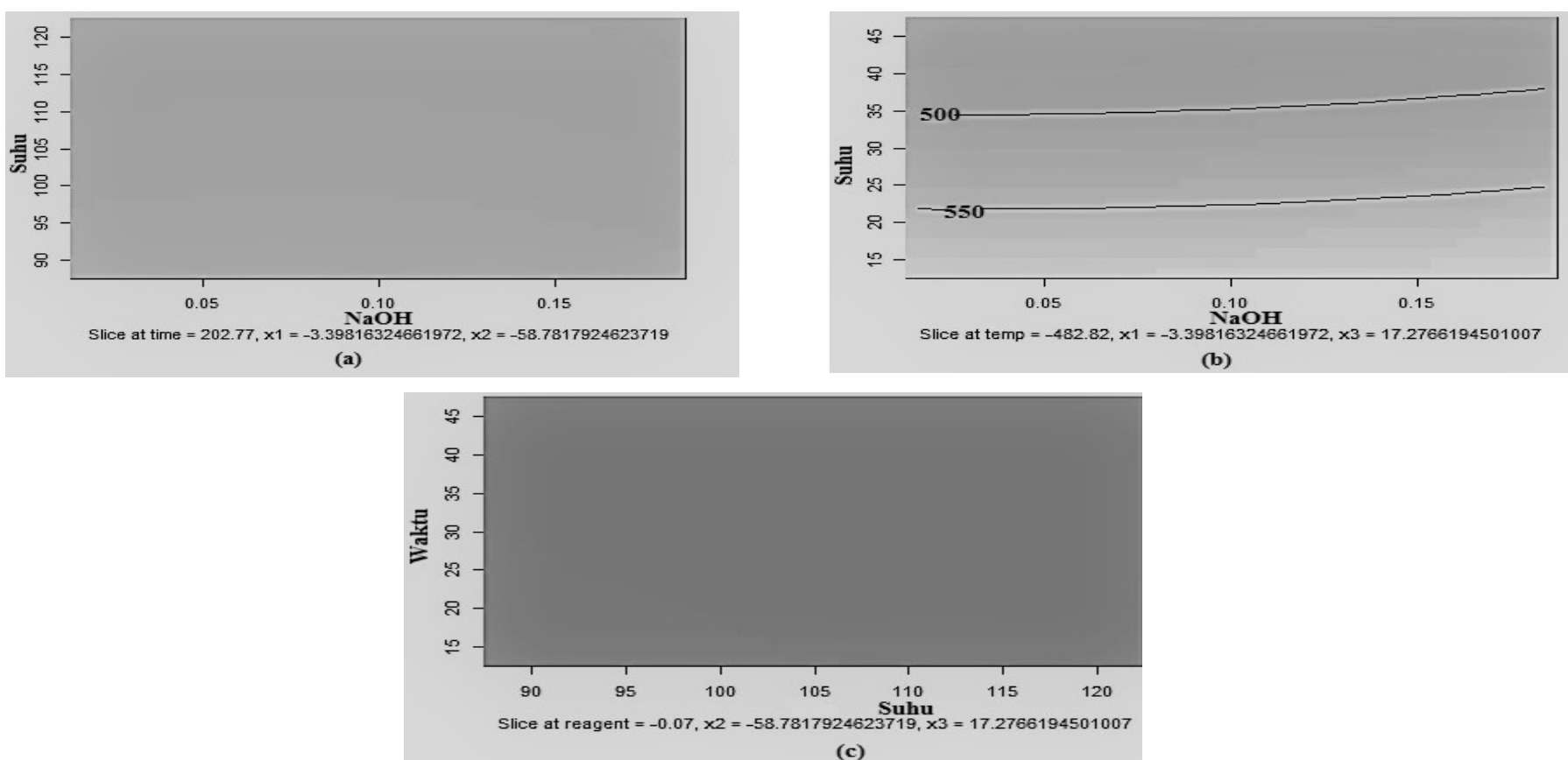

Gambar 5. Kontur rendemen bobot fibroin A. atlas dengan satu kali degumming, a) kombinasi konsentrasi $\mathrm{NaOH}$ dan suhu, b) kombinasi konsentrasi $\mathrm{NaOH}$ dan waktu, dan c) kombinasi suhu dan waktu 

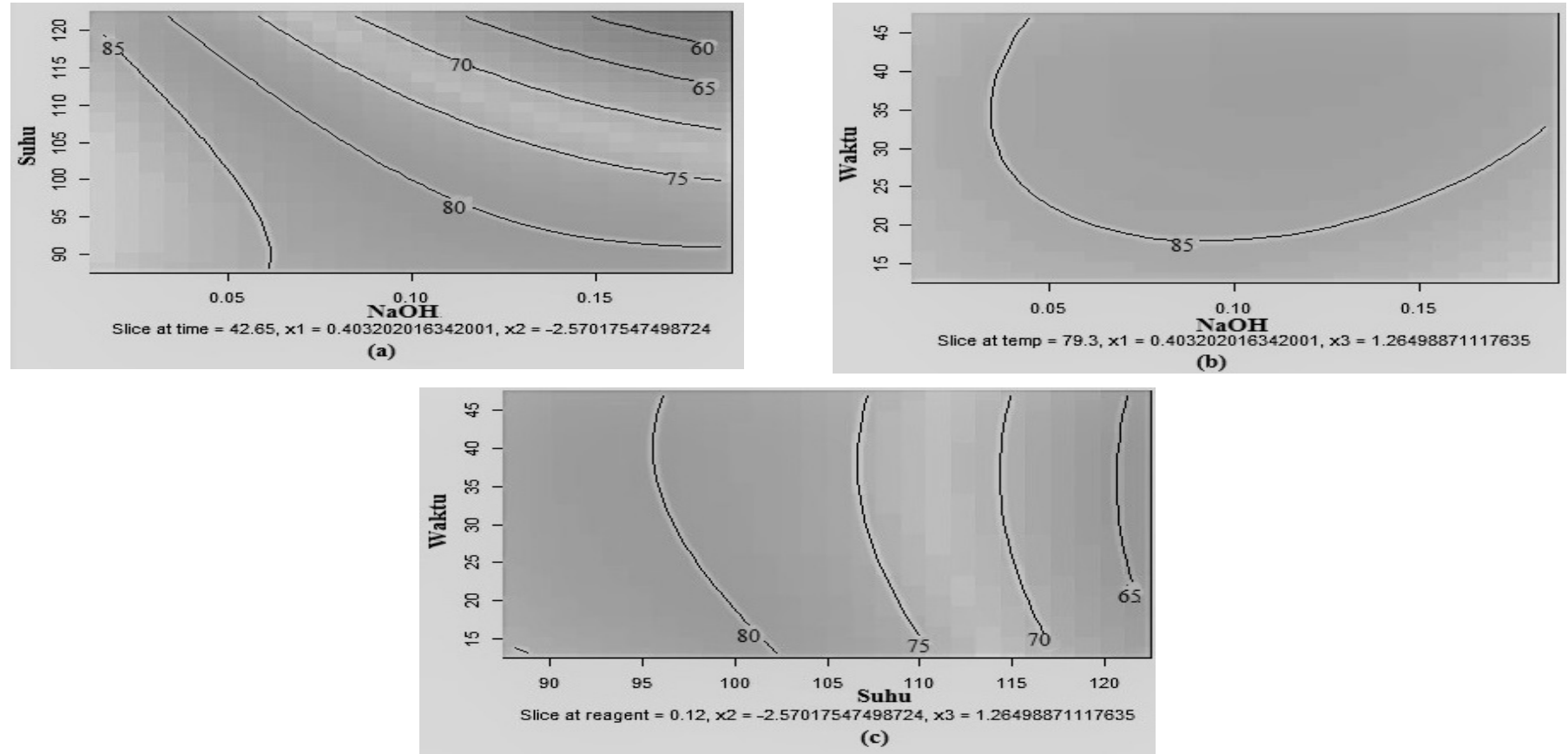

Gambar 6. Kontur rendemen bobot fibroin A. atlas dengan dua kali degumming, a) kombinasi konsentrasi $\mathrm{NaOH}$ dan suhu, b) kombinasi konsentrasi $\mathrm{NaOH}$ dan waktu, dan c) kombinasi suhu dan waktu

rendemen bobot fibroin sesungguhnya pada kondisi optimum yang diperoleh Program RSM meskipun optimasinya masih saddle point. Verifikasi hanya dilakukan pada kondisi optimum dua kali degumming (DIIa) karena untuk mencapai kondisi optimum pada satu kali degumming (DIa) dibutuhkan alat yang berbeda dari yang digunakan sebelumnya sehingga dikhawatirkan ada bias data. Selain itu juga perhitungan respon berdasarkan Persamaan 5 menghasilkan rendemen bobot fibroin yang lebih dari 100\%. Kondisi optimum DIIa diulang hingga tiga kali degumming, yaitu DIIa1, DIIa2 dan DIIa3 karena fibroin $A$. atlas belum terlihat bersih dari

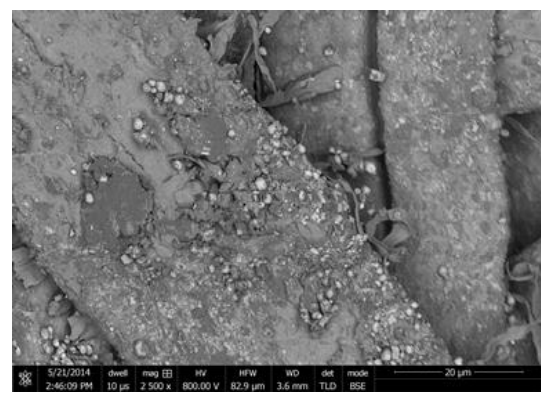

(a) serisin (foto SEM Gambar 7). Persentase bobot fibroin hasil penggulangan degumming pada kondisi optimum DIIa1, DIIa2 dan DIIa3 berturut-turut sebesar 87,45 $\pm 0,81 \%$, $83,06 \pm 1,50 \%$, dan $69,08 \pm 0,13 \%$. Hasil rendemen tersebut juga diverifikasi kembali dengan foto SEM (Gambar 7 dan Gambar 8). Hasil rendemen fibroin DIIa1 dan DIIa2 tidak berbeda nyata $(p>0,05)$, akan tetapi setelah cek foto SEM terlihat bahwa DIIa2 lebih bersih dibandingkan DIIa1. Oleh karena itu dua kali degumming pada kondisi optimum $\left(0,12 \mathrm{~N} \mathrm{NaOH}\right.$, suhu $79,3{ }^{\circ} \mathrm{C}$, dan waktu 42,65 menit $)$ akan direkomendasikan sebagai standar formula degumming pada

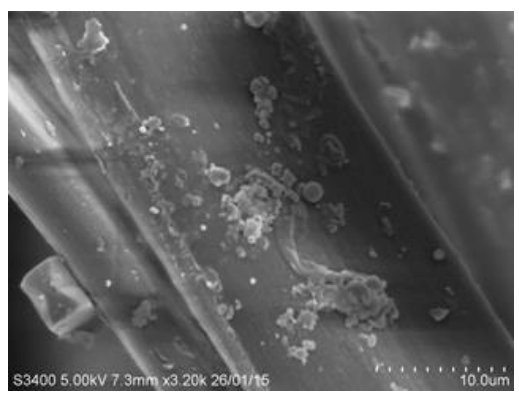

(b)

Gambar 7. Foto SEM Fibroin A. atlas, a) fibroin sebelum degumming, dan b) fibroin degumming pada $0,12 \mathrm{~N} \mathrm{NaOH}$, suhu $79,3{ }^{\circ} \mathrm{C}$, dan waktu 42,65 menit 


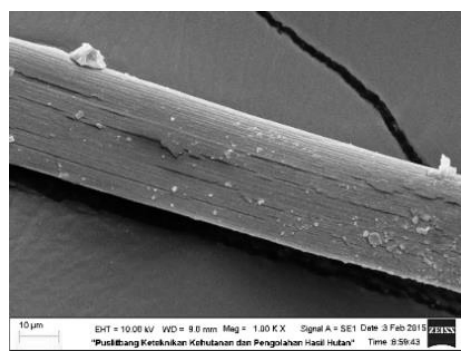

(a)

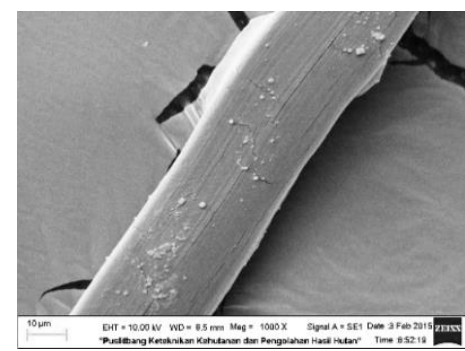

(b)

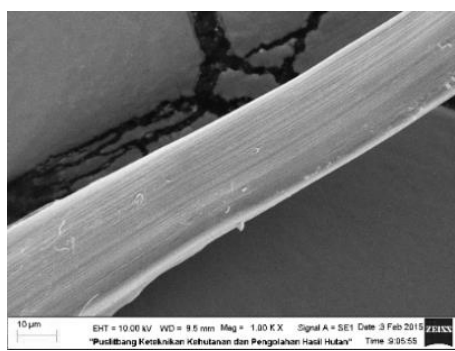

(c)

Gambar 8. Foto SEM fibroin A. atlas pada degumming $0,12 \mathrm{~N} \mathrm{NaOH}$, suhu $79,3{ }^{\circ} \mathrm{C}$, dan waktu 42,65 menit, a) satu kali degumming, b) dua kali degumming, c) tiga kali degumming

A. atlas. Perolehan rendemen fibroin pada penelitian ini dapat digunakan sebagai referensi karena belum ada yang mengkaji tentang optimasi rendemen fibroin $A$. atlas.

\section{Kekuatan Tarik Fibroin}

Kekuatan mekanik serat dapat di uji dengan pengujian Kekuatan Tarik serat tunggal. Hasil uji Kekuatan Tarik fibroin memperlihatkan bahwa perlakuan degumming dengan $\mathrm{NaOH}$ menurunkan kekuatan tarik baik pada fibroin $B$. mori maupun A. atlas (Gambar 9), sebesar 34-48\% untuk fibroin A. atlas dan 16-57\% untuk fibroin B. mori. Hal ini sesuai dengan hasil dari Nakpatom dkk. (2009), degumming dengan zat yang bersifat alkali akan menurunkan kekuatan Tarik fibroin B. mori sebesar 28-46\% dari kekuatan Tarik fibroin kontrol (tanpa penambahan alkali pada proses degumming

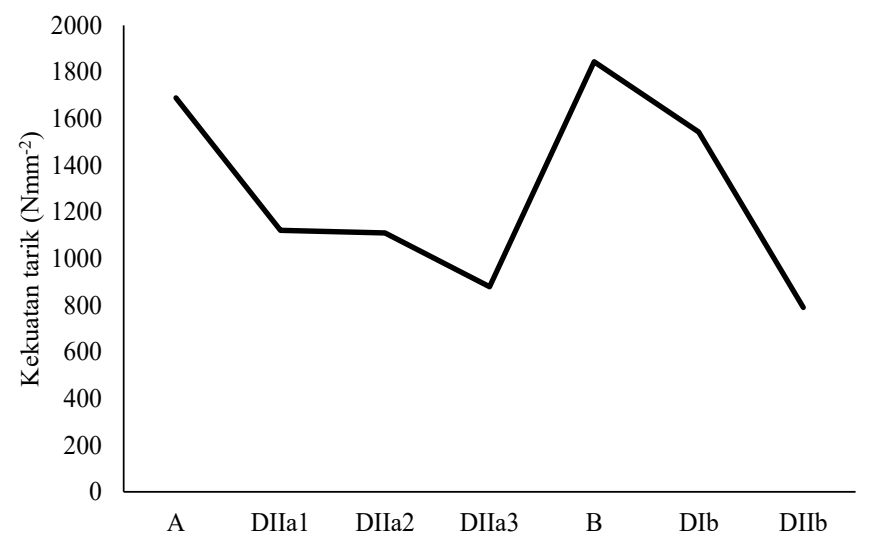

Gambar 9. Kekuatan tarik pada beberapa perlakuan fibroin. $\mathrm{A}=$ A. atlas sebelum degumming, $\mathrm{DIIa}=A$. atlas pada degumming 0,12 $\mathrm{N} \mathrm{NaOH}$, suhu $79,3{ }^{\circ} \mathrm{C}$, dan waktu 42,65 menit, DIIa1 $=A$. atlas pada satu kali degumming, DIIa2=A. atlas pada dua kali degumming, DIIa3 $=A$. atlas pada tiga kali degumming. $\mathrm{B}=B$. mori sebelum degumming. $\mathrm{DIb}=$ satu kali degumming pada $0,018 \mathrm{~N} \mathrm{NaOH}$, suhu $110,53{ }^{\circ} \mathrm{C}$ dan waktu 55,51 menit, dan DIIb dua kali degumming pada $0,12 \mathrm{~N} \mathrm{NaOH}$, suhu $83,18^{\circ} \mathrm{C}$ dan waktu 43,86 menit. nya). Kekuatan Tarik fibroin pada penelitian ini (sebesar 879$1689 \mathrm{~N} / \mathrm{mm} 2$ untuk $A$. atlas dan 790-1843 N/mm² untuk $B$. mori) juga masih lebih tinggi dibandingkan hasil dari Altman dkk. (2003) yaitu sebesar $740 \mathrm{~N} / \mathrm{mm}^{2}$ untuk fibroin B. mori dan $875-972 \mathrm{~N} / \mathrm{mm}^{2}$ untuk fibroin Nephila clavipes. Hal ini berarti formulasi degumming yang digunakan pada kedua spesies masih dalam tingkat wajar. Serat fibroin pada kedua spesies tersebut mempunyai potensi yang cukup besar dalam pemanfaatan usaha hilir ulat sutera yang membutuhkan spesifikasi kekuatan tarik yang besar.

\section{KESIMPULAN}

Kondisi optimum yang menghasilkan rendemen fibroin maksimal pada $B$. mori adalah satu kali degumming pada $0,018 \mathrm{~N} \mathrm{NaOH}$, suhu $110,53{ }^{\circ} \mathrm{C}$ dan waktu 55,51 menit dengan perolehan persentase fibroin sebesar $71,11 \pm 0,98 \%$. Kondisi optimum untuk $A$. atlas adalah dua kali degumming pada $0,12 \mathrm{~N} \mathrm{NaOH}$, suhu $79,3{ }^{\circ} \mathrm{C}$, dan waktu 42,65 menit yang menghasilkan persentase fibroin sebesar 83,06 \pm $1,50 \%$. Kekuatan Tarik dari fibroin menurun dengan adanya perlakuan pada degumming di kedua spesies (A. atlas dan $B$. mori), namun hasilnya masih lebih tinggi dari beberapa penelitian terdahulu. Kekuatan Tarik yang diperoleh $A$. atlas sebesar 879-1689 N/mm² dan B. mori sebesar 790-1843 N/ $\mathrm{mm}^{2}$.

\section{UCAPAN TERIMA KASIH}

Penulis mengucapkan terima kasih kepada Direktorat Jenderal Perguruan Tinggi (Dikti) yang telah memberikan Beasiswa Pendidikan Pascasarjana Dalam Negeri (BPPDN) pada tahun 2012. Atas beasiswa tersebut penulis dapat melakukan penelitian ini. 


\section{DAFTAR PUSTAKA}

Altman, G.H., Diaz, F., Jakuba, C., Calabro, T., Horan, R.L., Chen, J., Lu, H., Richmond, J. dan Kaplan, D.L. (2003). Silk based biomaterials. Biomaterials 24: 401-416.

Amiraliyan, N., Nouri, M. dan Kish, M.H. (2009). Electrospinning of silk nanfibers. I. An investigation of nanofiber morphology and process optimization using response surface methodology. Fiber and Polimer 10(2): 167-176.

Byung, M.M., Gene, L., So, H.K., Young, S.N. dan Taek, S.L. (2004). Electrospinning of silk fibroin nanofibers and its effect on the adhesion and spreading of normal human keratinocytes and fibroblasts in vitro. Biomaterials 25: 1289-1297.

Endrawati, Y.C. (2012). Ekstraksi Protein Serisin dari Kokon Sutera Liar Attacus Atlas dan Karakterisasinya sebagai Biomaterial. Tesis. Sekolah Pasca Sarjana Institut Pertanian Bogor, Bogor.

Fabiani, C., Pizzichini, M., Spadoni M. dan Zeddita, G. (1996). Treatment of waste water from silk degumming processes for protein recovery and water reuse. Desalination 105:1-9.

Gaspersz, V. (1992). Tehnik Analisis dalam Penelitian Percobaan. Tarsito, Bandung.

Lenth, R.V. (2010). Response Surface Methods in R, Using $R S M$. The University of Iowa, United States of America.
Masahiro, S., Hideyuki, Y. dan Norihisa, K. (2000). Consumption of silk protein, sericin elevates intestinal absorption of zinc, iron, magnesium and calcium in rats. Nutrition Research 20:1505-1511.

Mondal, M., Trivedy, K. dan Kumar, S.N. (2007). The silk proteins, sericin and fibroin in silkworm, Bombyx mori Linn. Caspian Journal of Environmental Sciences 5(2): 63-76.

Moeliono, M. dan Itung, M. (2010). Optimasi gintiran dan degumming terhadap benang sutera sebagai bahan rompi anti peluru. Arena Tekstil 25(1): 1-10.

Myers, R.H. (1971). Response Surface Methodology. Allyn and Bacon Inc, Boston.

Nakpatom, M., Somboon, B. dan Narumol, N. (2009). Papain enzymatic degumming of Thai Bombyx mori silk Fibers. Journal of Microscopy Sociaety of Thailand 23(1): 142146.

Sashina, E.S., Bochek, A.M., Novoselov, N.P. dan Kirichenko, D.A. (2006). Structure and solubility of natural silk fibroin. Russian Journal of Applied Chemistry 79(6): 869-876.

Vepari, C. dan Kaplan, D.L. (2007). Silk as a biomaterial. Progress in Polymer Science 32: 991-1007.

Zhang, H., Magoshi, J., Magoshi, Y., Yoshida, H., Chen, J.Y. dan Saiki, K. (2002). Inorganic compositions and thermal properties of cocoon fiber. International Journal of Society Material Engineering Resource 10(1): 113-116. 